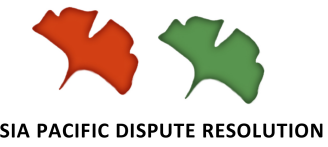

\title{
TRACING CHINA'S HIV EPIDEMIC: A STORY OF CROSS-BORDER GEOPOLITICS
}

\author{
Elanah Uretsky \\ George Washington University
}

\author{
APDR Working Paper Series \\ Volume 3 Number 1
}

ISSN 2371-6304

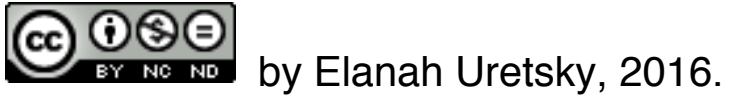

This article is made available as part of the Asia Pacific Dispute Resolution Working Paper Series and is licensed under a Creative Commons Attribution-NonCommercialNoDerivatives 4.0 International License (CC-BY-NC-ND) 


\section{TRACING CHINA'S HIV EPIDEMIC: A STORY OF CROSS-BORDER GEOPOLITICS \\ Elanah Uretsky \\ George Washington University}

The story of China's HIV epidemic began in 1989 with the discovery of 146 cases of the virus among injection drug users who lived in Dehong Prefecture, an area in Western Yunnan Province near the Burmese border (Ma 1990). Nearly all those infected were part of either the Dai or Jingpo ethnic minority communities. In fact, HIV was primarily a problem of ethnic minority communities for over a decade after the virus was first discovered in China when a mere eight percent of the population bore thirty-six percent of the disease burden (Kaufman and Jing 2002). It was also primarily a rural problem. The Chinese government initially paid little attention to HIV believing the virus would have a hard time spreading from such a remote region to more centrally located and populous areas. It took only six years though until HIV was detected in all of China's thirty-one provinces and municipalities.

This type of epidemic pattern is very unusual in the global narrative of HIV that has developed over the past three decades (Patton 2002). HIV is typically found in an urban metropolis and spreads to more remote, rural areas when rural to urban migrants return home. This chapter discusses the paradoxical trajectory that China's HIV epidemic has taken and the important role that its border with Burma plays in determining this unique epidemic pattern.

Borders are often seen as boundaries - no man's lands that simply serve as a division between two nation-states. But aside from their function as containers of economic and political influence, borders are also living and breathing entities for the people who inhabit such regions. Life in the border is different and must be accounted for as such. The Sino-Burmese border has economic and political significance for both of the nation-states that straddle its length. Locally, though, it holds different significance and meaning. An explanation of the significance of this border to both local and national authorities explains why China's HIV epidemic has defied global patterns of HIV. It also highlights the need for directing more programmatic and policy related attention toward this important and strategic border area. This paper will describe the nexus of local and national level relationships that converge in this remote but strategically significant region gained global recognition as the capital of China's HIV epidemic as the result of the 'perverse economy' that developed locally (Castells 1998); a black hole in the global economy that easily nurtures the development of an HIV epidemic. Manuel Catells speaks about such 'perverse economies' in many of the worlds forgotten border lands where there is no choice but to engage in illicit and illegal activities that increase risk for HIV. The black hole I describe, however, is different because it sits at the crossroads of Asia. 


\section{There is a Beautiful (and Strategic) Place-Ruili}

Visitors to Yunnan Province are daily greeted by the meandering melody of the popular song There is a Beautiful Place (you yige meili de difang); a song written in 1958 about the city of Ruili that talks about the Dai people ${ }^{1}$ who inhabit hidden villages that form a chain among the plains where they raise cows and goats (mimi de zhaizi jinjin xianglian; pingping de bazi li gan niu yang), is often associated with Xishuangbanna, a prefecture in southern Yunnan that has built a large tourist industry around its indigenous Dai population. ${ }^{2}$ Today Ruili is home to approximately 110,000 people. Sixty-five percent of its inhabitants come from five different highland and lowland ethnic minority communities, ${ }^{3}$ the largest of which is Dai. The Jingpo community is also relatively large, giving rise to Dehong's official name of the Dehong Dai and Jingpo Autonomous Prefecture (dehong daizu jingpozu zizhi zhou). ${ }^{4}$ Approximately seventy percent of Ruili's permanent residents live in rural areas where they are dependent on simple agriculture that includes: rice, sugar cane, bamboo, rape (canola), a variety of tropical fruits, and a small coffee crop. ${ }^{5}$ The economy that has allowed Ruili to develop and flourish, though, is supported through official and unofficial trade in jade, gems (rubies and sapphires), timber (primarily teak), heroin, and methamphetamines. People also flock to Ruili from around China to gamble in the Chinese owned casinos that operate just over the border. ${ }^{6}$

Geographically Ruili is remote but has a historic significance that continues to affect contemporary reality in both China and Burma. Ruili served a major role as a staging area for China's defense against Japanese incursion during World War II. The American volunteer air corps known as the Flying Tigers, an integral part of the China-Burma-India Theater run under the direction of General Joseph Stillwell ('Vinegar Joe'), set up a border airbase in Ruili. So grateful are the people of Ruili to these efforts that they still invoke the name of the air corps (known in Chinese as feihu dui) and its leader Claire Chinault (che na de). 'Vinegar Joe' also stands prominently in their memories as the namesake to the section of the Burma Road that runs through Ruili, locally referred to as Stillwell Road (shidiwei lu). Today this road serves as the first section of the national highway 320 that begins in Ruili and ends in Shanghai. ${ }^{7}$ The SinoBurmese border area that comes through Ruili remains strategically significant for its economic and trade related opportunities as well as the role it plays in helping China manage relations with its ethnic minority communities. The state consequently extends every effort to maintain security at this border that has also become an important entry point into securing China's economic growth.

This geopolitical standing along with the prominent role Ruili plays in the history of China's HIV epidemic offers a lens into the intersection of meanings, stories and discourses that are responsible for the development and maintenance of the HIV epidemic in China (Treichler 1999); stories that often lead back to the crucial cross border relationship that defines this region. 


\section{The Lives of Borders and Borderlands}

Epidemics, we are often told, do not recognize borders. This has been particularly true for HIV. The virus travels across fluid borders, where a combination of social disruption and economic isolation prompts the movement of illicit goods and people. Yet, while vulnerability to HIV is often heightened at border regions, most response efforts are limited by the boundaries of the modern nation-state (Lyttleton and Amarapibal 2002).

Borders have become significant as the symbol of the modern nation-state. They represent state sovereignty and protect state security. The borders that define the state are mere constructs of territorial power that often do not represent local reality. These political boundaries, which represent an official demarcation of national culture, do not always coincide with cultural boundaries that existed before the creation of the modern nation-state (Alvarez 1995, Wilson and Hastings 1998, Baud and Schendel 1997). Many people identify with the borderland rather than the nation-state because their culture does not adhere to the politically motivated assignment that officially divides their homeland. Borderlands are not recognized politically but they are important geopolitical elements because they embody an alternative culture that straddles political borders and sometimes even develop local economies characteristic of the particular borderland (Castells 1998, Hastings and Wilson 2001). This section discusses the border region that straddles the nations of China and Burma around the area of Dehong Prefecture, which lies inside of China's political borders but not necessarily its cultural boundaries.

Oscar Martinez (1994) speaks of four types of borderlands that include alienated borderlands, coexistent borderlands, interdependent borderlands, and integrated borderlands. Interdependent borderlands occur in regions where a symbiotic link between societies causes a considerable flow of economic and human resources over the border. This is juxtaposed to integrated borderlands, which exist in absence of barriers to trade and human movement. Baud and Van Schendel (1997) describe a lifecycle of borderlands that progresses from the infant stage to the adolescent and then to the adult borderland stage. China's border with Burma lies between these two taxonomies as an interdependent border at the adolescent stage of its lifecycle. The two sides of the border, have a very symbiotic relationship that is fostered by the close ties between ethnic kin, who officially hold citizenship in a single nation-state but who owe loyalty to their own ethnic territory that occupies the borderland. The Kachin, who live in the Kachin State on the Burmese side of the border, are closely connected and related to the Jingpo who live on the Chinese side of the border. The situation is similar for the Shan in Burma and the Dai in China. The tight ethnic networks that tie these people together across the border facilitate a fluid flow of resources and goods. Many recognize the border region as their homeland rather than one particular nation-state. This creates an adolescent borderland that is governed more by powerful and established cross-border networks than by the political barrier that divides the two nationstates. 
This type of interdependent borderland is characteristic of the area James Scott (2009) calls Zomia, a large geographic region that sits at the periphery of nine states. Yunnan is fairly central to Zomia, acting, as Scott says, as a 'shatter zone'; an area that serves as an out-of-the way haven for people seeking refuge from state and empire expansion, slave trade, war, and natural disaster. Dehong Prefecture's role as a shatter zone began several centuries ago when the Jingpo ${ }^{8}$ people migrated from northwest China. This path of migration continued into the Qing dynasty and the communist era. Many of the Han people who live in Dehong Prefecture today arrived during China's Great Famine (1958-1961) in search of the security offered by Dehong's dual annual rice crops.

The people who live in Zomia identify more with the region and are not fully incorporated into the nation-states that create seemingly artificial boundaries between ethnic kin. People in Ruili, likewise, consider themselves residents of a border region (bianjing diqu), which they argue faces certain challenges that outsiders cannot understand. Outsiders include both foreigners and people from the rest of China, which they refer to as the hinterland (neidi). Officially, China and Burma are divided and distinguished by a 2,192 kilometer border. But the official boundary is often arbitrary even to local officials who grant sovereignty over the region to local inhabitants. There are official border checkpoints that restrict the flow of goods and people from one nation to the other. But the rest of the border is porous and unguarded. Officials claim that only local peasants know where China ends and Burma begins. According to local folklore, while the region is split politically, the people live together in an environment where two countries share a village, a river, and even a single well.

\section{China's Economic Interests in Burma}

Like any neighboring countries, China and Burma depend on one another for economic trade and political stability, the two of which are intertwined. But as I will demonstrate in the upcoming sections, there are several competing levels of economic and political priorities at the central and local levels of government that complicate this relationship and result in its impact on the local HIV epidemic.

Burma was China's first friend following the communist takeover in 1949 but crossborder trade between the two countries was not opened until 1988. This milestone was initiated by a trade agreement signed between the Myanmar Import Export Corporation and the Yunnan Provincial Import Export Corporation to legalize cross border trade for private entrepreneurs, cooperative societies, and government organizations (Arnott 2001). ${ }^{9}$ This decision came at a time when Burma found itself isolated from the international community and in need of an ally that would help sustain its economy. At the time, Yunnan province was also in need of an outlet to boost its economy. China's decision to develop a market-oriented economy resulted in a process of fiscal decentralization. Provinces that once depended on fiscal outlays from the central 
government were suddenly faced with a need to finance their own local economies. ${ }^{10}$ The government's plan for promoting economic growth on the east coast included the development of special economic zones that produce goods for export. Access to this coastal route was not possible for inland provinces like Yunnan and Sichuan though, so the government looked toward Burma as a possible avenue for export from the western part of the country (Lintner 2002).

This prompted a local trade industry that rebuilt Ruili, a remote city at the edges of the world, into a vibrant local economy. Ruili has a goal of becoming the next Shenzhen. ${ }^{11}$ Promoting an economically vibrant city at the far reaches of the country not only benefits the local government but also supports the national goal of maintaining security. Ruili feels more like a livable city than a border outpost because of its modern infrastructure and clean appearance. It benefits from updated telecommunication and electric systems and a small but well developed system of roadways inside the city. In 2007 Ruili alone carried out 5 billion RMB (approximately USD 650 million) of foreign trade. Two-thirds of the total was represented by exports to Burma (Guo 2010). Goods also flow in the opposite direction. Many Chinese businessmen profit from the ability to freely import both licit and illicit goods across this porous border, including jade, gems, timber, and heroin. Trade in legal goods is facilitated through the tax-exempt free trade border zone of Jiegao that was established to increase trade between the two countries. Jiegao was a small village situated on the opposite bank of the Ruili River from Ruili, and technically sits on soil outside of China's jurisdiction. All the resources that are processed in Jiegao are tax free, which increases official trade between the two countries. Trade figures would increase exponentially if it accounted for smuggled jade, rare timbers, which are officially illegal in China, and the heroin that flows easily over the porous border.

In an environment that is arguably governed more by money than bureaucratic authority, trade of any kind is valued because it brings needed revenue to the area that facilitates economic growth. Facilitating this free flow of trade also helps maintain stability and security in a region that serves as a nexus for the transport of oil and gas, resources vital to China's national economic interests. Stopping the trade in illicit goods would likely incite violence in an area that is now relatively stable and consequently threaten the regional security that is so important for China's national interests.

\section{Development of a Unique 'Perverse' Local Border Economy}

An examination of how this crucial border area serves both local and national economic interests to Burma and China helps to explain why an HIV epidemic could emerge in such a remote location. The Sociologist Manuel Castells writes about the informal economies that develop at border areas as 'perverse' economies that naturally nurture HIV epidemics. He describes these areas as 'black holes' because of their isolation from the global economic and financial network. As a result, people in these regions must turn to informal economies that rely 
on arms dealing, smuggling, illicit drugs, selling of sex, children, or even human organs (Castells 1991). A similar "perverse" economy exists at the Sino-Burmese border and is sustained and promoted by two governments that depend on the exchange of illicit goods and services in order to maintain economic and regional security. . This has resulted in an economy that is not only perverse but also large enough to sustain the governments and communities on either side of the border. They have in effect created their own micro-economy that in aggregate links up with the global economy.

The economy that has developed at the Chinese-Burmese border is slightly different, though, from what Castell's describes at other disconnected border areas that have nurtured the development of local HIV epidemics. Unlike other areas with perverse economies, this region is resource rich ${ }^{12}$ but perverted by the authoritative bureaucracies that govern either side of the border. The economy in this region also seems more organized and deliberate than the typical border economies Manuel Castells discusses. There is certainly an air of the wild, wild West typically seen in many border regions but the environment is tamed by the strength of a local government that works hard to maintain stability through building the formal economy while also facilitating the informal economy that supports the city. This also presents challenges to any plans to disrupt this informal economy because of the important role it serves to official plans for economic growth and security on either side of the border.

The 'perverse economy' that developed at China's border with Burma is operated by and for the region despite the fact that it straddles two independent nation-states with their own economies and laws. The region had to therefore find ways to legally overcome some of the national level policies that limited their growth and development. One example of such a strategy came with development of a special license plate issued only for this border region. Chinese license plates, regardless of location, are all blue with white letters and numbers. They are only distinguished by a single character on the left side of the plate that denotes the province or municipality of origin. A license plate from Beijing is denoted by a jing (京) and a license plate from Yunnan is denoted by a yun (云). All license plates from Dehong Prefecture begin with a 云 $\mathrm{N}$, denoting the prefecture within the province where the car is registered. But Dehong once released a black license plate with red lettering that was preceded by a jing (竟), the character meaning border. This 'red plate' (hong pai) 红牌 was issued only to traders who traveled within the border area. The cars that carried the hongpai were also only legally permitted to drive within the border area. Such a legal and administrative dispensation was possible under the Regional Ethnic Autonomy Law, which grants permission to autonomous areas to adopt special policies and flexible measures that can aid their economic and cultural development. In this case the administrative exception was made to stimulate trade in an economically undeveloped but strategically important region.

The hongpai was born during an era of strained economic relations at the border. Burma stopped trade with all its neighbors (including China) in 1997 as a way to protect its weakening economy 
from the Asian Financial Crisis (IDEA 2001) . Recognizing its economic reliance on goods from Burma, the Dehong government conversely allowed a continued flow of goods from Burma (Dupont 2001, Porter 1997). A local trade industry with Burmese businessmen was facilitated through development of this special license plate that recognized their trading status only within Dehong Prefecture. These privileges were eventually extended to Chinese businessmen who wanted to take advantage of importing Burmese resources after the border's closing to trading activities. This variation in an administrative law was minor yet it helped sustain the local economy in Ruili, which was dependent on its trade with Burma. The hongpai was phased out, however, in a provincial effort to gain more control over the region as it increasingly became important to national strategic interests that depended on building infrastructure for official trade and transportation of oil and gas reserves from Burma to China. A July 2004 announcement from Dehong Prefecture required all hongpais to be off the road by July 2005 in order to standardize vehicles used to engage in cross-border trade (2005). ${ }^{13}$. The hongpai served a specific purpose to businessmen in Dehong that many residents felt was incomprehensible to anyone from the hinterland (neidi). Local businessmen believed the new requirements were thus unwarranted and only put in place by bureaucrats wishing to assert more government control over this region that essentially lived and operated outside the framework of official Chinese law. Such a decision was necessary from the state's perspective, however, as a way of avoiding threats to national security and stability, in the country's sensitive border areas (Saich 2001).

\section{Maintaining Stability on the Chinese/Burmese Border}

Maintaining stability in a region constantly balancing the needs of local and national governments and communities who all exercise different levels of power requires orchestrating a careful dance between the various stakeholders..

Borderlands are often knit by networks of kin that straddle the national boundary and possibly extend around the globe. Alone, the people living on the periphery of a nation are weak. The cross national bond that exists between ethnic kin living on either side of an official border, however, can pose a threat to the stability of a border region used to protect national security (Castells 1998). The threat to national loyalty and national security is further compromised around borders, which are often informally controlled by local chiefs who compete for power and authority with the state. The Kachin/Jingpo society, which straddles the Chinese-Burmese border at the point of Dehong Prefecture is governed by a dual social structure described as gumsa and gumlao. ${ }^{14}$ The gumsa structure, that still governs contemporary Jingpo society, is a hierarchically organized society ruled by a chieftain (Wang 1997).

The modern day Chieftain for the Jingpo community in Ruili is represented by a man named Dong Lecheng, who is also very influential in the local political economy. Dong's influence derives less from political position and more from a high social and economic position that has 
grown into political influence. Dong Lecheng was born in 1969 and grew up in a rural village in Longchuan County ${ }^{15}$ that did not have access to a road during his childhood. Army service gave him access to the outside world and also training in several useful skills. He began his postmilitary career as a driver for the local public security bureau. His subsequent entrepreneurial career began trading timber with Kachin kinsmen from the Burmese side of the border. He diversified into gems in the 1990's and his business ventures have now grown into a corporate enterprise called the Jingcheng Group. ${ }^{16}$ The enterprise gains public recognition from a sixteen story four-star hotel but also includes businesses in land development, infrastructure and construction, a private bank that specializes in microcredit, and the first private airline in Yunnan Province, which took its maiden flight after Spring Festival in 2014. He also owns real estate in Beijing and operates some of the large casinos in the Kachin State. ${ }^{17}$ Dong Lecheng is married to a Han woman whose father is a high level official in one of China's major banks. This gave him access to capital as well as influence with the local government. His private business venture maintains close alliance with the governments of Dehong and Ruili, often drawing on government capital to fund new ventures. These partnerships increase Dong's local political leverage and also help to develop Dehong economically.

Dong Lecheng's position as an actor who assumes the role of a border chief who regularly negotiates with the nation-state (Baud and Schendel 1997, Hastings and Wilson 2001, Sturgeon 2004) has helped transform him into an influential agent in Ruili both in government circles and within the Jingpo community itself. This relationship, however, is equally important for the state. Like all successful businessmen operating in China, Dong is co-opted by the state (Dickson 2008) to a certain extent even while maintaining the level of authority required to unofficially reign over the local Jingpo community. As a result, there seems to be a certain amount of quid pro quo between Dong and the state. For example, through his networks of kinship Dong Lecheng continues to have the flexibility to operate casinos in the Kachin State that cater to Chinese patrons despite repeated attempts by the government to close down casinos over the border. But he is also loyal to the Chinese state. He operates establishments that allow officials in Ruili to entertain the constant stream of visiting officials. In 2012 he also funded all the major road construction projects in Dehong Prefecture. This relationship of reciprocity allows Dong Lecheng to prosper as a businessman and leader in the local Jingpo community, where he is revered as their modern day Chief, while simultaneously granting the government the necessary entrée required to assert control over the local region.

Presence of an influential local chief like Dong Lecheng is antithetical to the nationalistic projects that are part of the goals of the nation-state. Most states aim to dissolve loyalties at their border regions by making politicians at the periphery resemble their counterparts in the interior portions of the country (Baud and Schendel 1997). This nurtures an atmosphere of national loyalty throughout the country. Until such a goal can be reached, however, stability at the borderland depends on maintaining good relations with the borderland chiefs who have the greatest amount of influence and authority over the networks of people who inhabit borderlands. 
As a result, borderland elites often become integrated into networks of central state power and act as allies of the state in its efforts to control borderland society. They are in effect coopted by the state where both can benefit from their strained relationship. In this dual role they claim loyalty to the state but are ultimately most loyal to the ethnic networks they serve and protect. Dong Lecheng's entrepreneurial efforts have been very beneficial for economic growth and development in Dehong but the government's allowances on his part have also benefited the local Jingpo population. While it may seem like two competing interests are getting into bed with one another, failing to incorporate these elites into state structure could result in a breakdown of state power and control at the border (Sturgeon 2004, Baud and Schendel 1997).

Maintaining the balance in these relationships plays an important role not only in achieving economic growth in Dehong but also in achieving the country's strategic and economic goals. Economically, Ruili is the gateway to a valuable source of oil and gas reserves. Strategically, it offers protection to a potential US military incursion. The official party line promotes an argument that US forces are waiting for Burma to weaken so they can invade China from the southwest. These stories always amused me as some sort of locally produced folklore that perhaps grew out of the love that has ensued between Kachin and Jingpo toward Americans since the late nineteenth century when they were 'rescued' by an American missionary. ${ }^{18}$ Nevertheless, this theory drove reality. Both the Chinese and Burmese governments felt a 'real' threat from US incursion that translated into local action. In November 2005 "astrological predictions and fears of invasion by the United States" sent Burma's entire military junta into hiding in a secret underground military compound as they awaited aid from the Chinese government in averting the American threat (Mydans 2005). For China the prophecy is playing out as renewed relations between Burma and the US are widening the distance between Burma and China. Burma's decreased economic and political dependence on China is threatening China's reliance on Burma.

\section{Maintaining Security at the Border}

Local and national government are perhaps most concerned about a threat to stability from a 'pan-Kachin' movement that can result from the strongly networked Jingpo society that straddles the border. Jingpo society is defined by 'unity'. All Jingpo and Kachin, no matter where they live, treat each other as brothers and follow a strict code of mutual aid for other members of their society ( $\mathrm{Wu}$ and Yang 1996). This theme of unity is further represented through the strict rules for marriage that create an unbreakable kinship circle because people with the same surname cannot marry. Glutinous rice is also used in ritual meals to represent social unity.. However, political influence from the CCP has caused cultural rifts between the Jingpo and Kachin because of the prohibition against religion in China. Kachin communities center on the church and pastor, a structure that is not sustainable under the communist party in China. This has weakened unity between the Kachin in Burma and the Jingpo in China. Many Jingpo 
realize this limits their ability to create a powerful political society. Nevertheless, the Chinese government still perceives the threat from the unified Jingpo culture, which motivates much of their attitude toward the Jingpo and Kachin.

The result is a government that works hard to maintain friendly relations and a balance of power between ethnic communities and the military government in Burma through things such as . provision of basic utility services like water, electricity, and telecommunications (phone and internet) (2009) ${ }^{19}$ Economic security is also crucial for stability. In an area where the economy is largely informal, this translates into development of an environment capable of fostering trade in heroin, timber, people, and the services and goods necessary for nurturing an active casino industry. The casino industry in particular has been fraught with volatility because the government must weigh its potential contribution to the economy against its contribution to violent crime that threatens stability at the border. The casinos that line the Burmese side of the border are usually built and managed by Chinese businessmen who lease land from the Kachin Independence Organization (KIO). They draw a large influx of tourists to the $\operatorname{area}^{20}$ and also employ a large number of rural residents from Dehong Prefecture. The casinos also support a large prostitution industry, which poses further potential for the spread of sexually transmitted infections, including HIV.

Border stability is further maintained by balancing the protection of national security with a recognized need to ensure the economic salience of local ethnic communities. Relations with the Kachin government are central to this effort because of their level of organization. The Kachin are believed to be one of the best organized armed opposition groups in Burma (Smith 1994b), with close ties to their Jingpo kin on the Chinese side of the border. In fact, the KIO is the only government of an independent ethnic minority state in Burma permitted to operate an office in China (one in Ruili and one in Kunming); an allowance that facilitates security and stability with the Kachin/Jingpo community. Stability at the border is further underscored through the maintenance of relations with local ethnic borderland elites like Dong Lecheng. The state's support of Dong Lecheng has helped to build his wealth and social capital. In turn the state gains unfeterred access to this crucial border region. Dong Lecheng is also typical of border chiefs in that he remains detached from the state while benefiting from his proclaimed loyalty. As a local elite, however, he has become a border guardian for the state. This helps maintain his power base and the cross border connections that, like many border chiefs in this region, allow him to channel useful information and illicit goods across the border (Baud and Schendel 1997, Sturgeon 2004).

\section{The Need to Balance Relations}

The importance of negotiating minority-majority relations is as important to China's goal of socialist construction and social transformation today as it was when Mao first stressed this 
priority in $1956 .{ }^{21}$ In Dehong, as in other strategic ethnic border regions, there are daily reminders of the need to carefully navigate these sensitive relationships. The ethnic communities, which comprise a majority of the local population are permitted their own identity but the culture is politically controlled by the Han state. This dynamic is perhaps most evident in the way major ethnic holidays are celebrated in Dehong. Both the Dai and the Jingpo celebrate a major annual holiday. The Dai celebrate Water Splashing Festival (poshuijie) in mid-April ${ }^{22}$ and the Jingpo celebrate the holiday of munaozongge, which falls at the fifteenth day of the first lunar month. Both are marked with major events that bring the community together. Such a major gathering could pose a threat to the state. Rather than cause tension by prohibiting such an organized gathering, the state has chosen to sponsor official celebrations of the major ethnic holidays in the county seats. They do, however, prohibit locally organized events in individual villages.

Munaozongge is a festival steeped in animist traditions that celebrates a major transition in Kachin history and society that occurred as result of their migration from the Tibetan Plateau. ${ }^{23}$ The festival is celebrated through organization of a three-day long celebration where community elders lead the entire community in the sacred dance of the munao. Common folklore dictates that the munao was first danced when the God of the Sun invited the birds to dance in the heaven. ${ }^{24}$ The tradition was eventually passed onto humans. The elders who lead the dance continue to honor this origination story in their costumes for the dance that include a headdress adorned with three types of bird feathers (including peacock feathers) and representation of a condor beak. The festival is initiated with the sacrifice of a bullock or a buffalo. Packets of meat are then distributed to invite the host's relatives and neighbors to the celebration. The dance then officially commences when two elders signify they are ready by waving raspberry branches over their heads and leading the community into the local munao square. Kachin/Jingpo communities are traditionally centered on a munao square, which is identified by the traditional Kachin totem that depicts the gendered organization of the culture as well as their creation myth. ${ }^{25}$ They dance in a circular pattern around the totem that follows an ' $S$ ' shape reminiscent of the route the Kachin took from the Tibetan Plateau to their current homeland.

Government organized festivals centralized in each county seat have supplanted the small village level celebrations of Munazongge. These standard three-day county level festivals are initiated by all the official pomp and circumstance one has come to expect from a communist party event. Speeches by local and prefectural officials stress the importance of the Jingpo community as well as the value of their cooperation with the Han government. This allows the government to maintain control over the expression of local culture while also demonstrating its official support for local ethnic minority communities. The Ruili and Dehong governments have also extended sponsorship of munaozongge celebrations in Burmese communities as China's relations with Burma become increasingly important. ${ }^{26}$ 


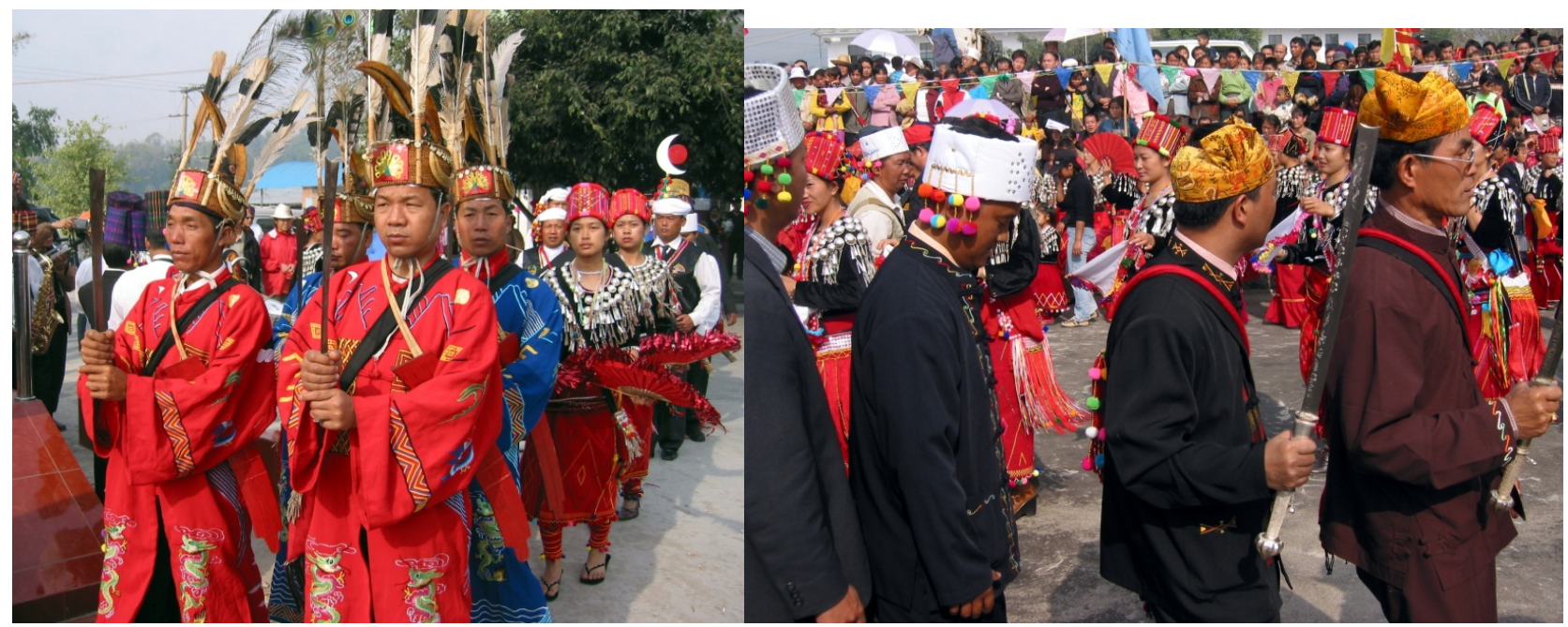

Jingpo elders initiating Munaozongge

Jingpo Officials opening Munaozongge

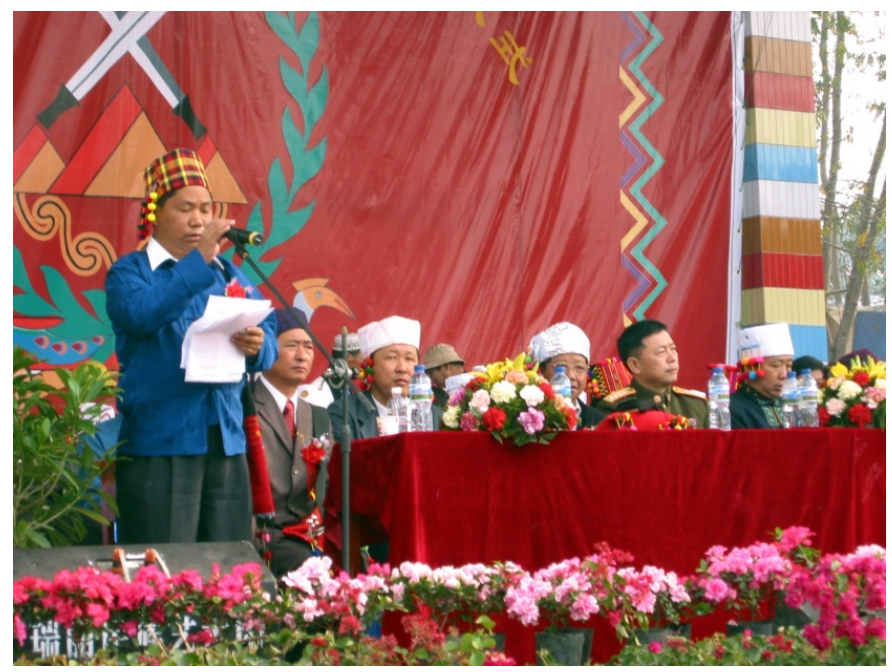

KIO officials at Ruili Munaozongge

This type of friendly diplomacy of shared cultural ideals also helps to maintain the political relationship between China and Burma. In 1999 the government of Dehong decided to mark the Pauk Phaw relationship, established through Zhou Enlai's 1954 visit to Rangoon, with an official annual holiday called China-Myanmar Friendship Festival (zhongmian baobo jie in Chinese). This three-day festival is celebrated during the first few days of May in order to coincide with the Golden Week ${ }^{27}$ that centers around the May Day holiday. The celebration includes lots of pageantry with floats and dance troupes representing communities from both sides of the border. The good will built through the boabo jie festival also underscores other jointly celebrated holidays including International Women's Day and ethnic minority festivals like poshui jie and munao zongge jie. 
The complex set of relationships between local and national, minority and majority actors that result in this good will works to maintain stability. But as Janet Sturgeon noted in her research at the crossroads between China, Burma, and Thailand, it also provides the perfect environment for an explosive growth in opium, heroin, and amphetamine trade that is equally important in stabilizing these relationships It is not an accident that heroin catalyzed the HIV epidemic in this region of the world. Consequently, it is important in responding to this epidemic to understand the history behind its cultivation and use.

\section{China's History with Opiates}

Opium has played a prominent role in the history of the Chinese state and Chinese society since the sixteenth century. Socially, opium serves as a marker for elite men. It also provided a valuable source of revenue that was used for state building at the local and national levels during the nineteenth and twentieth centuries (Baumler 2000). To the public, opium also had valuable medicinal uses. It was an effective treatment for symptoms from malaria, dysentery, and cholera. It was also a useful analgesic and antitussive and was often used to cope with fatigue, hunger. diarrhea, rheumatism, and cold (Dikötter, Laamann, and Zhou 2004). People in Dehong Prefecture still view opium as an effective treatment for some of the most common ailments that plague the region.

In the West opiates are associated with a type of deviance characterized by addiction. In China, however, opium assumed meanings of status and loyalty. Opium was a valuable social lubricant for elite men. Much like the cigarettes offered in contemporary Chinese society (referred to as fayan) to open communication between male friends and colleagues, opium served as a 'welcome smoke' (yingchou 迎抽) ${ }^{28}$ that demonstrated hospitality and sociability during imperial times. Opium use was popular among high-level government officials and people who occupied various other high profile roles in society. Of note, Jonathan Spence mentions Chen Duxiu's grandfather, Feng Yuxiang's parents, Hu Shi's stepbrother and Lu Xun's father ${ }^{29}$ in his comprehensive social history of opium smoking in China. But opium use was not only limited to the higher echelons of society. Eunuchs and laborers often smoked out of boredom (Spence 1992), which is also a common explanation I heard about why so many ethnic minority men smoke opium in Dehong Prefecture. In Dai and Jingpo cultures, women typically bear the brunt of the work in the fields while men stay at home. Their idle time, combined with the cheap price of heroin so close to the border has promoted a large epidemic of injection drug use.

Opium has also been central to Chinese state building efforts. After the Taiping rebellion (18501864) opium provided the revenue necessary for rebuilding local economies. Political reformers like Zhang Zhidong (1837-1909) and Li Hongzhang (1823-1901) ${ }^{30}$ also realized its value in their self-strengthening efforts as a way of financing special projects and repaying loans (McMahon 2002, Spence 1992). In the twentieth century opium served as a crucial source of revenue for the 
Kuomintang (KMT). The KMT did make efforts to control opium during the Republican era but warlords who saw opium as a lucrative source of taxable income were reluctant to adhere to such measures. There is even evidence that opium supported communist state building efforts during the Yenan period ${ }^{31}$ (Baumler 2000, Chen 1995, Dikötter, Laamann, and Zhou 2004, Slack 2000, Zheng 2005).

Opium prohibition in China was prompted by the nationalistic movement that took hold in the mid-Qing period as a backlash against encroaching foreign imperialism. Opium became a tool for nationalists who were looking for a scapegoat for the catastrophic faults that resulted from imperialism. Anyone loyal to opium was accused of being loyal to an imperialist product; an addiction that was unacceptable under a nationalist regime (Dikötter, Laamann, and Zhou 2004, McMahon 2002). This also contributed to acceptance of the disease theory of addiction. Suddenly the opium user was transformed from an elite socialite into a heartless, slippery addict who was capable of breaking family ties, disrespecting their elders, and even selling their wife.

\section{The importance of opium in Yunnan borderland}

Opium has historically played an important role in Yunnan's economy because of a temperate climate that supports several annual harvests. 29,750 $\mathrm{mu}^{32}$ of land in Kunming alone was dedicated to opium production by the 1880's. Eradication would have deprived peasants of income from this large area of land (Spence 1992). China's borderland economy was also dependent on opium. Opium cultivation in Burma dates back to the sixteenth century and continues to play a large role in the country's economy (McMahon 2002, Spence 1992, Zhou 1999, Lintner 1999). ${ }^{33}$ The Kachin and Jingpo economies depended on opium sales to buy daily necessities (Wu and Yang 1996, H'o 2007). In 1956 (the last year opium cultivation was permitted in China) opium sales comprised up to $63 \%$ of agricultural income for some Jingpo communities in Dehong Prefecture. ${ }^{34}$ Opium was primarily used as a means of currency that was traded for cattle and other necessities in Jingpo society but Wang Zhusheng reports that in 1953 a small part was consumed in the local area (Wang 1997). Writing in 1997 Wang says, "Even today the Jingpo economy remains closely connected with opium use and cultivation" (Wang 1997:77). This is partly due to the advantages that opium offers as a crop. Opium poppies are more feasible for hill paddy cultivation because they require less work and are easier to transport to market. The ease of transportation also reduces the cost of bringing the product to market, thereby increasing any profit that can be made from selling the crop. Its hardiness also limits any damage to the crop during the long journey from the mountains to the valley. Opium also does not deplete the soil of nutrients like rice or vegetables and it has many varied uses, which again, makes the crop more marketable. Aside from its most commonly perceived use for heroin production, opium plants can be converted into oil that can be used for food or lighting; the lower leaves can be eaten raw as a cold salad; ${ }^{35}$ the raw seeds can be used in cooking ${ }^{36}$; the 
remaining parts can be used as fodder; and the stalk can be burned and transformed into a sought after dye (Dikötter, Laamann, and Zhou 2004, Lintner 1997).

The support for opium goes beyond its economic utility for local residents to the political utility it holds in supporting this strategic border area. Sources as early as 1950 trace support for the Burmese opium trade to the KMT and CIA. It is believed that the CIA used revenue from opium production to support military operations of KMT soldiers who had escaped to Burma in 1949 in order to "resist the advance of Chinese communism" (Arnott 2001:74). The Communist Party of Burma also turned to opium trade as a way of maintaining their armed struggle against Rangoon after Chinese assistance was reduced following the accession of Deng Xiaoping in 1978 (Arnott 2001). Many have also argued that the cease fire agreements between the SLORC and many ethnic states have supported growth of the opium trade since 1988 (Ball 1999). Absence of international trade and aid caused the SLORC to turn to the many precious resources available in the ethnic states as a means of revenue to support the country's economy. This created a situation of strange bedfellows brought together by economic need. The resulting informal economy has contributed equally to the SLORC's state building efforts as it has to the maintenance of Burma's strongest ethnic states (Chang 2004).

Trade in opium, heroin, and other commodities that are illegally transported over the border is sustained through large and intricate networks based on kinship, reciprocity, and patron-client relations that are difficult to penetrate or even describe but are important because they form the basis of these large local informal economies. Unlike formal economies that depend on global financial networks, informal economies typically develop among culturally and ethnically rooted regional networks like the ones that exist at China's border with Burma. Such organizations benefit from strong alliances of unity and codes of honor that help maintain their strength and capacity for preservation. Similar to formal economies, these economies are also global in nature. Local regional networks are supported by the global networks of organizations that share similar cultural roots and provide access to a market that demands local goods and resources. In many cases, regional networks can influence politics and law enforcement, much like we have seen in Dehong. The political strength of these networks also promotes an environment that presents significant challenges to efforts to stem the use of drugs (Castells 1998).

Networks that support the drug trade across the Chinese-Burmese border are not new. Much of the trade that originates in Yunnan is facilitated through trafficking networks that descended from the Chinese triads, which began as mutual aid societies in the eighteenth century and only later became involved in opium trading (Dupont 2001, Murray 1994). Alliances among ethnic kin in northeast Burma and Yunnan allowed a more direct trafficking route to open up once China established trade agreements with Burma. Ethnic groups in Burma who have traditionally been cut off from the country's central economy established patronage relations with local farmers to support their operations after Burma's independence in 1948 when they first suspected they would not be integrated into the new Burmese government. These border polities remain, creating an environment where local ethnic minorities still rely on local villages 
to provide grain in return for protection (Sturgeon 2004). They are supported by larger networks of officials who facilitate the elements necessary for moving goods over 'borders ${ }^{37}$ in exchange for taxes, levies, and tribute (Yawnghwe 1993). Ethnic links across the border into China have allowed these communities to maintain the staple of their economy through established kinship networks despite their supposed political division between two nation-states. There also seems to be little government motivation to control drug trafficking. The Burmese junta has been largely supported by hard currency derived from the drug trade and the gifts officials receive from the heroin factories. Drug traffickers also have strong ties with high-level officials in Yunnan and other major areas on the international drug trade route like Fujian and Guangdong (2009, Steinberg 2001). These dynamics enhance the importance of the dance that local and national officials must conduct at the border area with each other and with the ethnic minority communities that influence stability in the region.

\section{Happiness (kaixin) at the Border: Defining a Local Socio-political Culture}

Stories of HIV typically describe a population and a causal agent, like heroin and injection drug users, as the motivation for an epidemic. The recipe for an HIV epidemic is not always so simple though, particularly at a complex border region where different cultures, economies, and political systems meet. The epidemic narrative I recount in this chapter describes a situation that is neither discrete nor measurable but one that places the causal factors at the intersection of a diverse set of cultural and geopolitical cues (Taleb and Blyth 2011). Ruili is home to a unique cross border culture of a carefree population that enjoys access to a rich reservoir of resources but must also adhere to the restrictions of an authoritarian government. Those who live in Ruili and Dehong emulate a culture of happiness (kaixin). Provincial and central level officials have the power and authority to curtail the flow of goods that supports the local economy and culture but refrain and look the other way in the interest of national security. This perverse geopolitical environment has nurtured the development of the HIV epidemic in China.

Governing in Ruili and Dehong Prefecture is a constant challenge for officials under pressure to please their superiors. Performance evaluation for government officials in the market reform era is largely dependent on achieving national goals that include population planning and economic growth (Saich 2006). This can be difficult to officially achieve in an area like Dehong whose economic success is largely the result of an informal economy. In addition, local officials must ensure provincial and central level officials that they are maintaining the level of stability necessary for protecting national security at this crucial border area. Consequently, local officials often find themselves negotiating between the requirements necessary for maintaining their vibrant informal economy and those necessary for pleasing the people 'upstairs'. On one hand, Ruili can take full advantage of being in a remote location where the Emperor is far away. However, because they are so important to national security, Ruili and Dehong's continued 
success also rely on satisfying the needs of the many high level provincial and even central level officials who often come to survey (kaocha) the local area. They solve this dilemma by making provincial and national level officials happy (kaixin).

\section{Having a good time in Ruili (zai ruili wan de kaixin)}

Happiness (kaixin) is not only a way of life in Ruili, it is also important for political survival. Successful local officials share their local way of happiness (kaixin) with official visitors through constant hosting and entertaining (yingchou) (Uretsky 2008) to ensure they leave Ruili with a good impression and not one of an area that engages in illicit trade and transgresses national policies. Those who do have a good time (wan de kaixin) are usually willing to either ignore or even help to protect the many illicit industries that support the local economy. This has transformed Ruili into a local and even national playground where such favors are exchanged for the ability to engage in these activities and share in the happiness and good times that are part of the local culture. As many as two hundred officials from around the country can arrive at once to share in this local cultural attribute. Many are entertained in venues built and operated by Dong Lecheng. ${ }^{38}$ As one retired official explained to me, "When the big leaders (da lingdao) come down to visit, you have to make sure they are happy (kaixin) because the local leaders (lingdao) depend on them for promotions and salary raises." If they are not satisfied they leave Ruili with a bad impression. But the simple provision of food, drink, and entertainment that may include a gift of a pretty girl (song meinü) is sufficient to satisfy the whims of an official visiting from a higher position in the vertical system of governance.

Visitors to Ruili are entertained from the moment they wake in the morning until the time they go to sleep. Daylight hours are filled with trips to fieldsites to evaluate official work (kaocha) but also to popular local restaurants where the host treats his guests to local delicacies of fried bee pupae, or sa pie (a dish of cold rice noodles dipped in a bitter mix of cilantro, garlic chives, lime juice, raw chopped beef, and cow bile) and offers his guests long reverential toasts over baijiu that usually include a wish for the guest to be happy and have a good time in Ruili (zhu ni zai ruili wan de kaixin). At night they are treated to karaoke, massage (anmo), foot reflexology (xijiao), hair washing (xitou), or a sauna (sang na) and any of those services can be accompanied with the services of a sex worker; popular forms of entertainment in China that they can carelessly enjoy even more in such a remote location. In exchange, visiting officials offer career advancement or a blind eye to the industries that support the local economy that supports the stability of this complex region of ethnic and national relations that is so crucial to national security and regional economic growth.

Global responses to the HIV pandemic are frequently bound by epidemiologic paradigms of risk that have trained us to recognize how groups organized around constructed identities of 'highrisk' behave within the context of the nation state. They have also trained us to believe that HIV 
is the result of faults that are easily treated through very directed methods and mechanisms that target behavior change. Illicit drug problems can be eradicated through crop replacement programs and sex workers can be taught alternative skills. Harm reduction and prevention education programs can protect health in the absence of successful eradication programs. Such paradigms, however, neglect the roles that these agents play in local cultures and economies. Responding to HIV in China requires an understanding of the complex cultural, political, and economic context that supports trade in the opium that ignited this epidemic. This type of response is not only dependent on behavior change communication or harm reduction but must also engage the complex networks of kinship, ethnicity, and local and international politicoeconomic webs that have a stake in protecting China's economic and strategic positions in the region.

\section{Bibliography}

Dehong Zhou Renmin Zhengfu hongpai guanli gonggao (A Public Announcement on the Adminstration of Red Plates from the Dehong Prefecture People's Government). 2005

"China's Relations with Myanmar: Welcome, Neighbor." The Economist, September 11, 2010.

Alvarez Jr, R.. 1995. The Mexican-US Border: The Making of an Anthropology of Boderlands. Annual Review of Anthropology, 24:447-470.

Arnott, D. 2001. China-Burma Relations. In Challenges to Democratization in Burma: Perspectives of Multilateral and Bilateral Responses, edited by International Institute for Democracy and Electoral Assistance. Stockholm, SE: International Institute for Democracy and Electoral Assistance.

Ball, D. 1999. Burma and Drugs: The Regime's Complicity in the Global Drug Trade. Canberra, AUS: Australian National University, Strategic \& Defense Studies Center.

Baud, M., and Van Schendel, W. 1997. Toward a Comparative History of Borderlands. Journal of World History, 8 (2):211-242.

Baumler, A. 2000. Opium Control versus Opium Suppression: The Origins of hte 1935 Six-Year Plan to Eliminate Opium and Drugs. In Opium Regimes: China, Britain, and Japan, 1839-1952, edited by T. Brook and B.T. Wakabayashi. Berkeley, CA: University of California Press.

Brautigam, D. 2009. The Dragon's Gift: The Real Story of China in Africa. New York: Oxford University Press.

Castells, M. 1991. The Informational City: A New Framework for Social Change. Toronto: Center for Urban and Community Studies, University of Toronto. 
Castells, M. 1998. End of Millenium. Malden, MA: Blackwell Publishers.

Chang, W.C.. 2004. Guanxi and Regulation in Networks The Yunnanese Trade Between Burma and Thailand, 1962-1988. Jounal of Southeast Asian Studies, 35 (3):479-501.

Chen, Y. 1995. The Blooming Poppy under the Red Sun: The Yan'an Way and the Opium Trade. In New Perspectives on the Chinese Communist Revolution, edited by T. Saich and H. Van de Ven. New York: M.E. Sharpe.

Dickson, B. 2008. Wealth into Power: The Communist Party's Embrace of China's Private Sector. New York: Cambridge University Press.

Dikötter, F. , Laamann L., and Xun Z. 2004. Narcotic Culture: A History of Drugs in China. Chicago: IL: University of Chicago Press.

Donnan H., and Wilson T. 2001. Borders: Frontiers of Identity, Nation, and State. New York: Berg.

Dupont, A. 2001. East Asia Imperilled: Transnational Challenges to Security. New York: Cambridge University Press.

Falco, M. 1995. Don't Cooperate with Burma's Military Regime. Burma Debate.

Guo, X. 2010. Boom on the Way from Ruili to Mandalay. In Myanmar/Burma Inside Challenges, Outside Interests, edited by L. Rieffel. Washington, DC: The Brookings Institution.

H'o, Ts'ui-p'ing. 2007. Rethinking Kachin Wealth Ownership. In Social Dynamics in the Highlands of Southeast Asia: Reconsidering Political Systems of Highland Burma by E.R. Leach, edited by F. Robinne and M. Sadan. Boston: Brill.

IDEA, International. 2001. Challenges in Democratization in Burma: Perspectives on Multilateral and Bilateral Perspectives. Stockholm, SE: International Institute for Democracy and Electoral Assistance.

International Crisis Group. 2009. China's Myanmar Dilemma. In Asia Report No. 177. Washington, DC.

Kaufman, J, and Jing J. 2002. "China and AIDS: The Time to Act is Now". Science Magazine. June 28, 2002, June 28, 2002.

Komlosy, A. 2004. Procession and Water Splashing: Expressions of Locality and Nationality During Dai New Year in Xishuangbanna. Journal of the Royal Anthropologic Insittute, 10 (2):351-373.

Li, C. 2010. The Policies of India and China toward Myanmar. In Myanmar/Burma: Inside Challenges, Outside Interests, edited by Lex Rieffel. Washington, DC: The Brookings Institute. 
Liang, C.S.. 1990. Burma's Foreign Relations: Neutralism in Theory and Practice. New York: Praeger.

Liang, C.S.. 1997. Burma's Relations with the People's Republic of China: From Delicate Friendship to Genuine Co-operation. In Burma: The Challenge of Change in a Divided Society, edited by P. Carey. New York: St. Martin's Press.

Lintner, B. 1997. The Kachin: Lords of Burma's Northern Frontier. New Zealand: Sollo Development Limited.

Lintner, B. 1999. Burma in Revolt: Opium and Insurgency since 1948. Chiang Mai, Thailand: Silkworm Books.

Lintner, B. 2002. Blood Brothers: The Criminal Underworld of Asia. New York: Palgrave Macmillan.

Lyttleton, C, and Amarapibal A. 2002. Sister cities and easy passage: HIV, mobility and economies of desire in a Thai/Lao border zone. Social Science and Medicine, 54 (4):505-518.

Ma, Y. 1990. HIV was first discovered among IDUs in China. Chinese Journal of Epidemiology, 21 (6):184-185.

Martinez, O. 1994. Border People: Life, and Society in the US- Mexico Borderlands. Tuscon, AZ: University of Arizona Press.

McMahon, K. 2002. The Fall of the God of Money: Opium Smoking in Nineteenth-Century China. New York: Rowman \& Littlefield Publishers, Inc.

Murray, D. 1994. The Origins of the Tiandihui: The Chinese Triads in Legend and History. Stanford: Stanford University Press.

Mydans, S. 2005. "Looking for the Bumese Junta? Sorry it's gone into Hiding." The New York Times, November 14, 2005.

Myint-U, T. 2011. Where China Meets India: Burma at the New Crossroads of Asia. New York: Farrar, Straus and Giroux.

Pai, G. 2004. "Jiaqiang lingdao, tongyi sixiang: youxiao yufang he kongzhi aizibing" (Strengthening Leadership and Unifying Ideas: Effective HIV Prevention and Control). In Conference on 2004-2010 Strategic Planning of AIDS Prevention in Ruili Ruili, Yunnan.

Patton, C. 2002. Globalizing AIDS. Minneapolis, MN: University of Minnesota Press.

Porter, D. 1997. A Plague on the Borders: HIV, Development, and Traveling Identities in the Golden Triangle. In Sites of Desire, Economies of Pleasure: Sexualities in Asia and the Pacific, edited by L. Manderson and M. Jolly. Chicago: University of Chicago Press. 
Potter, P. \& Jacobs, L. 2006. Selective Adaptation and Human Rights to Health in China. Health and Human Rights 9(2): 112-134.

Saich, T. 2001. Governance and Politics of China. New York: Palgrave.

Saich, T. 2006. Social Policy Development in the Era of Economic Reform. In AIDS and Social Policy in China, edited by J. Kaufman, A. Kleinman and T. Saich. Cambridge, MA: Harvard University Asia Center.

Scott, J. 2009. The Art of Not Being Governed: An Anarchist History of Upland Southeast Asia. New Haven, CT: Yale Univerisity Press.

Silverstein, J. 1997. The Civil War, the Minority and Burma's New Politics In Burma: The Challenge in a Divided Society, edited by Peter Carey. New York: St. Martin's Press.

Simon, S. 2011. Between China and India Lies Myanmar's Future: An Interview with Thant Myint-U. In Weekend Edition Saturday: National Public Radio.

Slack, E., Jr . 2000. The Naitonal Anti-opium Association and the Guomindang State, 19241937. In Opium Regimes: China, Britain, adn Japan, 1839-1952, edited by T. Brook and B.T. Wakabayashi. Berkeley, CA: University of California Press.

Smith, M. 1994a. Ethnic Groups in Burma: Development, Democracy, and Human Rights. In Human Rights Series. London: Anti-Slavery International.

Smith, M. 1994b. The Question: Humanitarian and Development Aid in Burma? Burma Debate.

Spence, J. 1992. Opium. In Chinese Roundabout, edited by Jonathan Spence. New York: Norton.

Steinberg, D. 2001. Burma: The State of Myanmar. Washington, DC: Georgetown Univeristy Press.

Sturgeon, J. 2004. Borders, Practices, Boundaries, ad the Control of Resource Access: A Case from China, Thailand, and Burma. Development and Change, 35 (3):463-484.

Taleb, N.N., and Mark Blyth. 2011. The Black Swan of Cairo: How Suppressing Volatility Makes the World Less Predictable and More Dangerous. Foreign Affairs, . 90 (3):33-39.

Treichler, P. 1999. How to Have Theory in an Epidemic: Cultural Chronicles of AIDS. Durham, N.C.: Duke University Press.

Tsui, K.Y., and Wang Y. 2004. Between Separate Stoves and a Single Menu. The China Quarterly, 177:71-90. 
Uretsky, E. 2008. Mobile Men with Money: The socio-cultural and politico-economic context of 'high-risk' behavior among wealthy businessmen and government officials in urban China. Culture, Health and Sexuality, 10 (8):1-14.

Wang, Z. 1997. The Jingpo: Kachin of the Yunnan Plateau. Tempe, AZ: Program for Southeast Asian Studies, ASU.

Webster, D. 2003. The Burma Road: The Epic Story of the China-Burma-India Theater in World War II. New York: Farrar, Strauss, and Giroux.

Wilson, T.M., and Donnan H. 1998. Nation, State, and Identity at International Borders. In Border Identities: Nation and State at International Fronteiers, edited by T. Wilson and D. Hastings. New York: Cambridge University Press.

Wu, Y., and Y Yang. 1996. Dehong shizhi ziliao (Materials for the Dehong Gazetteer). Mangshi, Yunnan, China: Dehong Ethnic Press.

Wu, Z., and Yongsheng Y. 1996. Dehong shizhi ziliao (Materials for the Dehong Gazetteer). Dehong Ethnic Press.

Yawnghwe, C.T. 1993. The Political Economy of the Opium Trade: Implicaitons for the Shan State. Journal of Contemporary Asia, 23 (3):306-326.

Yawnghwe, C.T.. 1995. Shan Opium Politics: The Khun Sa Factor. Burma Debate.

Zheng, Y. 2005. The Social Life of Opium in China. New York: Cambridge University Press.

Zhou, Y. 1999. Anti-Drug Crusades in Twentieth Century China: Nationalism, History, and State Building. New York: Rowman and Littlefield Publishers, Inc.

\footnotetext{
${ }^{1}$ The Dai people are one of 55 ethnic minorities that comprise China's population

${ }^{2}$ Xishuangbanna, or Sipsongpanna in Thai, is located near China's border with Laos. To learn more about Xishuangbanna please read Sandra Hyde (2006). "Eating Spring Rice: The Cultural Politics of AIDS in Southwest China e" and Sara Davis (2007) Song and Silence: Ethnic Revival on China's Southwest Borders

${ }^{3}$ The five ethnic minorities in order of population size include the: Dai, Jingpo, De'eng, Lisu, and Achang communities

${ }^{4}$ This type of official bureaucratic designation is assigned to counties, prefectures, and provinces that are predominantly populated by a specific ethnic minority in order to promote the cultural practices of China's ethnic minority communities in conjunction with national practices.

${ }^{5}$ This is quickly changing as the government buys land from rural peasants to transform into residential and commercial space on its march toward economic growth and development.

${ }^{6}$ Gambling, which is so popular in China, is nevertheless illegal. Many Chinese people evade prohibitions on gambling by crossing Chinese borders to visit Chinese owned casinos in the border regions. There are many Chinese owned casinos just over the Chinese border in the Kachin and Shan states in Burma although the Chinese government still manages to exert some control over their operation. Consequently there is great fluctuation in number and availability of casinos on the Burmese side of the border at any given time.
} 
${ }^{7}$ For a complete descriptive account of the Burma Road and General Stillwell's direction of the China-Burma-India
theater see (Webster 2003)
${ }^{8}$ The Kachin and Jingpo people are the same ethnic minority community. They are referred to as Kachin in Burma and Jingpo in China. I use the word Kachin to refer to the Burmese community and the term Jingpo to refer the Chinese community. Kachin/Jingpo refers the community as a whole. Here I use the term Jingpo to refer to the entire ethnic community that migrated from northwest China to southwest China and Burma because their native literature usually refers to the ethnicity as Jingpo (Jinghpaw in their language).

${ }^{9}$ Arnott argues that substantial trade already existed before the legalization enabled through this agreement.

${ }^{10}$ While China's economy is still technically controlled under a centralized plan, market reforms placed onus on individual governments to finance their own social development and welfare systems. Officials of individual governments are also now evaluated on the amount of economic growth that takes place in their jurisdiction. For more on the decentralization of China's economy see (Tsui and Youqiang 2004)

${ }^{11}$ Shenzhen is one of the first Special Economic Zones (SEZ) developed under China's export oriented market economy in the 1980's.

${ }^{13}$ Since the hongpais were meant to facilitate Burmese trade into China, they were issued to Burmese cars, which are all right hand drive cars. This also caused a proliferation in a small cottage industry of discarded cars from Japan that somehow made their way to Burma, then smuggled into Jiegao and refurbished for sale at a very cheap price to local Chinese.

${ }^{14}$ Briefly the Gumlao system can be characterized as anarchistic and equalitarian. Gumsa tradition does not believe in social stratification by lineage, chiefdom, etc. Gumsa tradition is characterized more by complicated hierarchical relations between clans/lineages. Gumsa societies have a chief. The structure of these societies is much more detailed in Leach's book.

${ }^{15}$ Longchuan county is the neighboring county to Ruili is primarily populated by Jingpo

${ }^{16}$ Jing for Jingpo and cheng for city.

${ }^{17}$ The last two are certainly not official parts of the Jingcheng enterprise but do attract a lot of revenue for Dong Lecheng. Shuttle vans from the hotel to the casinos ran frequently while I was conducting fieldwork.

${ }^{18}$ Kachin and Jingpo people attribute progress in their society to a Swedish-American missionary who arrived in their region in the 1890's.

${ }^{19}$ Chinese water, telecom, and electricity service reaches across the border into Burma.

${ }^{20}$ Anyone who is not a permanent resident and lives in a hotel can be classified as a tourist. However, a large number of the people attracted to the casinos are long-term tourists who stay in Ruili for several months at a time and make their living from gambling. In 2003 the government of Ruili reported 29 million USD in tourism revenue (Pai 2004)

${ }^{21}$ In this 1956 Mao wrote a treatise title On the Ten Major Relationships, which stressed the need to overcome ten basic problems in order to strengthen the nation. Included among them was the need to improve the relationships between the Han nationality and the national minorities. He stressed the need to reduce Han chauvinism and improve relations between all nationalities so that socialist construction could benefit from the resources available in minority areas.

${ }^{22}$ Water Splashing Festival (poshui jie), often referred to as the Dai New Year, is celebrated annually on April 11, 12, 13. For more details on the history and customs related to poshui jie see (Komlosy 2004)

${ }^{23}$ The munaos can also be danced during special events to celebrate someone in the community who has succeeded in business, death of an important elder or noblewoman, infertile couples, building a new home, going into or winning a battle, movement of a village, and solving differences among family members (Wu and Yang 1996; Lintner, 1997).

${ }^{24}$ Jingpo folklore also attributes its origins to one-hundred species of birds

${ }^{25}$ The totem sits on a horizontal beam that has the head of a condor at one end and a tail on the other. Atop the beam sits four pillars with different circuitous designs that represent the possible routes from the Tibetan Plateau to the current Kachin homeland. There are also sun and moon representations that signify male and female and a sword and sheath in between two of the beams that are also represent gender division. The horizontal beam also depicts freezes of two, four, and six teets representing female cows, pigs, and humans in order to denote the important position of women in the culture.

${ }^{26}$ I describe government control over the Jingpo munaozongge celebration here. Celebration of the Dai poshuijie (Water Splashing Festival) has assumed the same government control.

${ }^{27}$ The Chinese government had designated three national holiday weeks as Golden Weeks (huangjin zhou) in 1999, including National Day (guoqin jie), Spring Festival (chunjie), and May Day (International Labor Day). Golden 
Week was so named because the government declared three days of national holiday and rearranged the rest of the work week so government employees could have seven days of continuous vacation. This was done to promote domestic tourism. The National Day Golden Week was suspended in 2003 due to SARS and in 2007 the government ended the Golden Week around May Day. Baobojie now coincides with the National Day Golden Week.

${ }^{28}$ This is a different word from the yingchou I speak about in other parts of the book that refers to social entertaining.

${ }^{29}$ Chen Duxiu was one of the cofounders of the Chinese Communist Party in 1921. Feng Yuxiang was an important Warlord during the period of rule of the Republic of China (1911-1949). Hu Shih was an important revolutionary figure in China's May Fourth Movement and the New Culture Movement (1919-1921), both student led movements which advocated a move away from feudalism and development of a modern vernacular. Hu received his Ph.D. in philosophy from Columbia in 1919. He later became the first president of Peking University and then served as Consul General to the United States in San Francisco. Lu Xun, known as the father of modern Chinese literature as well as an important revolutionary figure in China, also promoted the use of vernacular and the need to abandon China's feudal past.

${ }^{30}$ Zhang Zhidong and Li Hongzhang were major forces behind the Self-Strengthening Movement at the end of the Qing dynasty. Along with other reformers in the movement they aimed to strengthen China through the adoption of Western technologies.

${ }^{31}$ Yenan is known as the birthplace of the Chinese communist revolution. Located in northern China in Shaanxi Province, Yenan was near the end of the Long March (1937-1948) and thus became the focal point of the Chinese Communist Revolution in 1949.

${ }^{32} 1 m u=1.6$ acres.

${ }^{33}$ Burma produced thirty tons of opium annually when it gained independence from Britain in 1948. Opium was used in Burma, Laos, and Thailand to trade for bars of pure gold, which resulted in the region's appellation as The Golden Triangle. This continued to increase. In 1996-1997 it was estimated that annual output had increased by 8000 percent to at least 2500 tons of raw opium (Linter, 1999).

${ }^{34}$ Drug suppression was more difficult in Dehong because of its remote location and also because it was not 'liberated' until 1953.

${ }^{35}$ Restaurants in Dehong serve cold poppy leaves with a spicy tomato based dipping sauce. It is euphemistically called 'green' food.

${ }^{36}$ A popular dish in Ruili is yanzi doufu (tofu cooked with raw poppy seeds). The raw poppy seeds are illegal in China. I innocently tried to carry a bag to a friend in Beijing who had visited Ruili and enjoyed eating yanzi doufu. I was stopped at the airport in Mangshi where my poppy seeds were confiscated as contraband.

${ }^{37}$ I put the word borders in quotes here because, as Chao-Tzang Yawnghwe notes in his article, borders are basically meaningless and inconsequential in this situation. I too noticed during my fieldwork that borders were easily traversed and made invisible if a businessman had relationships with the right government officials on either side of the border.

${ }^{38}$ Officials stay in his hotels, if they go across the border to gamble they gamble in his casino, and they are entertained by singers and dancers in his local ethnic village (minzu cun). As of 2012 they can even play 18 holes on his golf course. 